\title{
Francisco Karam e suas contribuições para o campo jornalístico
}

\author{
Guilherme Gonçales Longo ${ }^{1}$ \\ Valci Regina Mousquer Zuculoto²
}

\section{Resumo}

Os estudos sobre a Teoria do Jornalismo na academia brasileira evidenciam diversos autores já consolidados como referências fundamentais do e para o campo jornalístico. Entre eles está o jornalista, pesquisador e professor aposentado da Universidade Federal de Santa Catarina, Francisco José Castilhos Karam. Este artigo tem como objetivo apresentar e refletir as principais questões teóricas e profissionais debatidas por Karam em sua produção bibliográfica de quase 30 anos, entre livros e artigos que abordam temáticas como a constituição do campo jornalístico, ética, moral e deontologia e o ensino de jornalismo, entre outros.

Palavras-chave: Jornalismo. Francisco Karam. Ética jornalística

\section{Abstract}

The studies concerning Journalism Theory in the Brazilian academy evidence many authors who are already consolidated as fundamental references to and for the journalistic field. Among them, is the journalist, researcher and retired professor from Universidade Federal de Santa Catarina, Francisco José Castilhos Karam. This

1 Mestrando do Programa de Pós-Graduação em Jornalismo da Universidade Federal de Santa Catarina, onde pesquisa a cobertura das Paralimpíadas Rio-2016 pela imprensa brasileira. Formado em Jornalismo pela UFSC. Bolsista CAPES. Membro do GIRAFA (Grupo de Investigação em Rádio, Fonografia e Áudio) e do GIPTele (Grupo Interinstitucional de Pesquisa em Telejornalismo). E-mail: guilherme.longo93@gmail.com

2 Profa. Dra. Do Jornalismo da Universidade Federal de Santa Catarina (Curso de Graduação e do Pós-Graduação em Jornalismo). Florianópolis/SC, Brasil. Pós-Doutora pela ECo/Pós UFRJ; Doutora em Comunicação pela PUCRS. Conselheira da ABEJ. Diretora da FENAJ e do SJSC. Coordenadora da Rádio Ponto UFSC e do GP Rádio e Mídia Sonora da Intercom. Líder do Grupo de Investigação em Rádio, Fonografia e Áudio (GIRAFA) e integrante do Grupo de Pesquisa Jornalismo e Conhecimento (ambos registrados no CNPq). E-mail: valzuculoto@hotmail.com

Revista Pauta Geral-Estudos em Jornalismo, Ponta Grossa v.5, n.2, p. 147-163, Jul/Dez 2018. 
paper intends to present and reflect on the main theoretical and professional questions debated by Karam in his bibliographical production of almost 30 years, amid books and papers that address issues such as the constitution of the journalistic field, ethics, moral and deontology, teaching of Journalism, among others.

Keywords: Journalism. Francisco Karam. Ethics in Journalism

\section{A trajetória de Karam no mercado e na Academia}

Nestes tempos contemporâneos em que o Jornalismo mais uma vez atravessa determinantes transformações e crises, sobretudo de credibilidade, é essencial que tanto a sua academia quanto sua área profissional busquem debatê-las e entendê-las à luz de autores já consolidados como referências fundamentais do e para o campo jornalístico. Isto para que, das compreensões, se possa extrair contribuições para movimentações e, principalmente, para que o Jornalismo se consolide como campo de conhecimento, se fortaleça e se valorize como profissão e assim, cumpra sua função fundamental de levar informação qualificada, plural e ética à sociedade, atendendo ao interesse público a que deve estar sujeito. Para tal, então, é preciso (re)debruçar-se nos estudos que constroem e consolidam a teoria do Jornalismo e, portanto, o campo na sua totalidade.

Neste arcabouço referencial se inclui a obra do jornalista, pesquisador e professor aposentado da Universidade Federal de Santa Catarina, Francisco José Castilhos Karam. Em sua produção bibliográfica de quase 30 anos, entre livros e artigos, Karam aborda temáticas como a constituição do campo jornalístico, ética, moral e deontologia e o ensino de jornalismo. O objetivo deste artigo é destacar e refletir sobre as principais discussões de Karam acerca dessas questões.

Gaúcho nascido em 1952, na cidade de Bagé, no interior do Rio Grande do Sul fronteiriço com o Uruguai, Francisco José Castilhos Karam tem uma trajetória profissional que o coloca como um dos principais pesquisadores em Jornalismo do país. Foi em Porto Alegre, capital do estado gaúcho, que Karam iniciou sua trajetória no campo jornalístico. Formado pela Pontifícia Universidade Católica em 1974, após concluir a graduação teve seu primeiro emprego, como revisor de textos na então Companhia Jornalística Caldas Júnior, que editava os jornais Correio do Povo e a já extinta Folha da Tarde, onde ficou até o final de 1976. 
Em sua carreira no mercado, passou por diversas redações de veículos nacionais e inclusive internacional. Trabalhou na Rádio Guaíba e jornal Diário do Sul e nas revistas Veja, Nova Escola, IstoÉ e Cláudia. Além disso, foi correspondente da Rádio Musical Nacional, de Cuba, entre 1988 e 1989.

Sua trajetória acadêmica começou em março de 1984, quando passou a integrar, por concurso público, o corpo docente da Universidade Federal de Santa Catarina, no Curso de Comunicação/ habilitação Jornalismo, ministrando disciplinas de Publicidade e Propaganda e Comunicação. Apenas dois anos após o ingresso na UFSC, em 1986, pela primeira vez já assumiu a Chefia de Departamento.

Em 1989, iniciou o mestrado no Programa de Pós-Graduação em Ciências da Comunicação na USP. Orientado pela professora Cremilda Medina, defendeu sua dissertação "A especificidade ética do jornalismo na universalidade humana" em 1993.

Entre 1996 e 1999, licenciou-se da UFSC para cursar seu doutorado, no Programa de Pós-Graduação em Comunicação e Semiótica pela Pontifícia Universidade Católica de São Paulo. Desse período, resultou sua tese "Retórica e Cinismo Ético em Discursos Empresariais Jornalísticos", orientado pelo professor Norval Baitello Júnior. Durante o doutorado, realizou um período-sanduíche na Universidade Autônoma de Barcelona, sob a supervisão de Lorenzo Gomis.

Após a obtenção do título de doutorado, continuou sua trajetória acadêmica como professor da UFSC, então já renomeado Curso de Jornalismo. Karam ministrou disciplinas como Teoria do Jornalismo, Ética e Deontologia do Jornalismo, Cátedra FENAJ / UFSC e Jornalismo no Cinema. Durante o ano de 2008, realizou sua pesquisa de pós-doutorado na Universidade Nacional de Quilmes, na Argentina.

Em 2007, foi um dos professores fundadores do Programa de Pós-Graduação em Jornalismo, o primeiro do Brasil, atuando como professor e como coordenador do programa durante uma gestão, de 2014-2016. Entre 2007 e 2015, orientou 8 dissertações no programa, com temas que foram desde teorias do jornalismo e retórica até jornalismo e cinema. No início de 2015, após a obtenção do título de Professor Titular na UFSC, Francisco Karam se aposentou das salas de aula.

Ao longo de sua carreira acadêmica, lançou os livros "Jornalismo, Ética e Liberdade" (1997) e "A Ética Jornalística e o Interesse Público" (2004), organizou, em coautoria, "Jornalismo Investigativo e Pesquisa Científica - Fronteiras" (2004, em parceria com Rogério Christofoletti) e "Jornalismo, Crítica e Ética" (2016, em parceria com Samuel Revista Pauta Geral-Estudos em Jornalismo, Ponta Grossa v.5, n.2, p. 147-163, Jul/Dez 2018. 
Lima), além de ter uma extensa produção de artigos. Francisco Karam desenvolveu uma produção científica essencial nos estudos em Jornalismo no Brasil, principalmente nos campos da Ética, Moral e Deontologia e Retórica e Dialética, nos quais se tornou referência.

\section{Retórica e dialética}

As influências do jornalismo fazem parte da obra de Francisco Karam ao longo de sua trajetória na academia. A Retórica e a Dialética, duas artes ou técnicas que envolvem a questão da fala originárias da Idade Antiga, receberam atenção especial de Karam, com artigos dedicados exclusivamente a essas temáticas.

A Retórica, que representa a técnica do bem falar e da comunicação eficaz e persuasiva, teria surgido no século $V$ a.C na Sicília e introduzida em Atenas pelo sofista Górgias, tendo em Aristóteles sua sistematização e as bases do estudo. Para Karam, a Retórica influenciou bastante o jornalismo e suas bases se fazem presentes até hoje.

Talvez por isso, conforme Xosé Lopez (2003: 387) o jornalismo, desde seu surgimento, viveu à sombra da velha tradição retórica antiga, clássica, medieval ou renascentista. Mesmo no ambiente do ciberespaço, destaca ele, o conceito de retórica é aplicável, de forma ampliada, ao ciberjornalismo, ou seja, transferindo para ele os procedimentos utilizados para que as mensagens na Rede sejam eficazes (KARAM, 2009, p. 111)

Algumas características do discurso retórico, são colocadas como necessárias para a eficácia do jornalismo, sendo que outras áreas, como o direito, também dependem bastante da retórica e seus processos, entre eles, a necessidade do discurso ser claro, convincente e envolvente aos interessados, informar, deleitar e comover, além da verossimilhança, credibilidade e legitimação (KARAM, 2012, p. 106).

Para Karam, as etapas da composição do discurso retórico (inventio, dispositio, elocutio, memória, actio ou pronunciatio), trouxeram bases fundamentais ao jornalismo, indo do fato à sua interpretação, do acontecimento às possibilidades distintas de narração, entre outros. Assim, se tornou possível a escolha dos temas, a seleção e hierarquização dos acontecimentos, o estilo... (KARAM, 2009, p. 114)

A ideia desenvolvida nos estudos da Retórica sobre o convencimento do auditório está presente nas aproximações com o jornalismo. Ele fica visível no fato de que um orador (no caso, o jornalista), precisa persuadir um público heterogêneo, de Revista Pauta Geral-Estudos em Jornalismo, Ponta Grossa v.5, n.2, p. 147-163, Jul/Dez 2018. 
personalidades, vínculos ou funções diferentes na sociedade. Assim, a "conquista do auditório" depende da utilização de múltiplos argumentos.

A aceitação do auditório perante o discurso jornalístico sobre os "fatos" pode ser vista, antes de mais nada, como um acordo que é mais ou menos aceito dependendo do "perfil do auditório" e da adequação do jornal às técnicas já consagradas e legitimadas pelo público (KARAM, 2011, p. 281)

Já a Dialética, é considerada um método de diálogo com foco na contraposição e na contradição de ideias, levando a um fluxo. Para Aristóteles, conforme reflete o pesquisador, a dialética é "um processo de dedução realizado com base em premissas que são apenas, e tão somente prováveis e por isso ela não pode ser considerada ciência, apenas discussão, probabilidade, uma forma não demonstrativa de conhecimento" (KARAM; HAUSER, 2011, p. 279). Assim como a Retórica, as noções envolvendo a Dialética, desde seu surgimento na Idade Antiga até seus debates mais contemporâneos, influenciam o jornalismo:

\begin{abstract}
A dialética no jornalismo, enquanto diálogo e controvérsia institucionalizada aparece como uma técnica com vistas a objetividade e a imparcialidade. O jornalismo é, de modo geral, muito mais retórico do que dialético na medida em que lida com um auditório universal e heterogêneo, o qual pretende convencer ou, de outro modo, adequar-se à ele (KARAM; HAUSER, 2011, p. 281)
\end{abstract}

A argumentação dialética, assim, aparece como uma principais bases do Jornalismo. É um dos fatores mais considerados para a construção da credibilidade jornalística, evidenciado como a dar visibilidade às discussões da sociedade, usando do artifício de dar voz a personagens com certo antagonismo e, desta forma, respondendo à necessidade de apresentar várias versões de um mesmo fato, por mais que não signifique necessariamente a construção de um debate. E justamente o real e efetivo debate do contraditório é que garantem ao Jornalismo a pluralidade necessária.

\title{
O campo jornalístico
}

As questões do campo jornalístico, que debatem, entre outros assuntos, a função, o sentido e a linguagem do jornalismo, estão entre os assuntos mais debatidos na literatura acadêmica. Mas até hoje não existe um consenso entre os pesquisadores. 
Quanto ao sentido do jornalismo, Karam vê nele a necessidade de uma construção coletiva. Em um primeiro momento, ele só pode existir se os jornalistas derem um sentido a ele. A partir daí, jornalistas e a sociedade precisam trabalhar em conjunto para a atribuição desse sentido. E acima de qualquer coisa, precisa estar o interesse público. Ou seja, interesses empresariais, pessoais, profissionais ou das fontes não devem se sobrepor aos demais.

Já a linguagem jornalística, depende de fatores que vão além do profissional jornalista. Para Karam (1997, p. 15),

A linguagem jornalística, texto escrito e imagem, necessita de algumas conexões com outros significados para os mesmos fatos. A diversidade de fontes que expresse a pluralidade social é indispensável para formar a compreensão do presente e permitir a intervenção mais consciente no futuro.

Uma de suas discussões desenvolvidas em "A Ética Jornalística e o Interesse Público" (2004, p. 39-42), é a definição e a existência (ou não) da objetividade dentro do jornalismo. Karam coloca que a objetividade é um dos preceitos da notícia no jornalismo, mas que existe também a corrente que defende a sua não-existência. Para ele, a objetividade existe e é algo defensável, que pode ser revelada através dos dados e fatos das notícias, além da maneira de viver. Só que se faz necessário entender que a objetividade possui, na realidade, um fundo subjetivo na sua construção, situando a escolha jornalística entre o "relevante socialmente e o dispensável jornalisticamente, o que não raras vezes deixa de ocorrer" (KARAM, 2004, p. 42). Ao colocar a compreensão acerca do subjetivo presente na busca da objetividade jornalística, ele argumenta que esta é permeada pelo ritmo da produção e da repercussão junto à sociedade:

A objetividade de um relato pode não ser a expressão sintética da complexidade do fato, mas certamente pode ser a revelação resumida da complexidade social. A redução com que o jornalismo opera corresponde ao ritmo de sua produção, à disseminação pública em períodos curtos e ampla escala daquilo que repercute ou talvez repercuta socialmente (KARAM, 2004, p. 39)

A questão organizacional e econômica do jornalismo representam a principal discussão de "A Ética Jornalística e o Interesse Público", abordando principalmente o seu uso como plataforma para defesa dos interesses dos donos dos veículos, algo que vai diretamente contra o que defendem os códigos de ética, que colocam o interesse público Revista Pauta Geral-Estudos em Jornalismo, Ponta Grossa v.5, n.2, p. 147-163, Jul/Dez 2018. 
acima de tudo. Segundo Karam, em casos como os das coberturas jornalísticas das privatizações realizadas no Governo de Fernando Henrique Cardoso, o Banco do Brasil e o subsídio ao papel-jornal, os códigos foram esquecidos nas gavetas. Considerou que tais coberturas se apresentaram diretamente contra o que é defendido em um documento que deveria ser tratado como essencial, o código de ética. Para Karam, tratou-se de um verdadeiro cinismo.

Exemplos como os citados na sua obra mostram uma relação clara entre poder político e a informação jornalística, o que "coloca sob suspeita expressões como isenção, direito do público à informação, interesse público, liberdade de escolha" (KARAM, 2004, p. 229). Conforma-se, assim, uma área em que fica difícil distinguir o que o seria jornalismo de interesse público e publicidade chamada de jornalismo (KARAM, 2004, p. 230).

Uma de principais aproximações teóricas ao longo de sua carreira é com Adelmo Genro Filho, que foi seu colega de docência. Professor do curso de Jornalismo da UFSC até sua morte no início de 1988, Adelmo é um dos autores mais citados por Karam, sobretudo devido à sua contribuição ao campo jornalístico e à teoria do jornalismo com o livro "O Segredo da Pirâmide", resultado de sua dissertação de mestrado.

Em artigo que faz revisão de "O Segredo da Pirâmide" para marcar os 20 anos do livro de Adelmo, assim Karam define sua importância para o jornalismo:

(...) uma abordagem densa e original sobre o jornalismo como forma de conhecimento, ultrapassando, entre outras perspectivas, a abordagem crítica negativa dada pela Escola de Frankfurt, ou a previsão de que seria um fenômeno apenas capitalista, consolidado no ápice da Revolução Industrial. (KARAM, 2007, p. 168)

Karam ressaltou diversas vezes a relevância fundamental e determinante da obra de Adelmo para o campo jornalístico. Isto, pela sua revisão de teorias pragmáticas sobre o jornalismo, críticas a tratamentos e abordagens deste no mundo capitalista e na ideologia socialista e em especial, pela construção de uma teoria que, segundo Karam (2007, p. 170), poderia ser aplicada ao cotidiano profissional jornalístico em qualquer sociedade. A conceituação principal do livro, a de que o jornalismo é uma forma de conhecimento cristalizada a partir do singular, não foi mais aprofundada pelo próprio Adelmo devido à sua morte, poucos meses após o lançamento de "O Segredo da Pirâmide" em 1987. 


\section{Ética, moral e deontologia}

Os estudos envolvendo a ética, moral e deontologia no âmbito jornalístico representam a principal parte da bibliografia de Francisco Karam. Seus dois livros de autoria própria, "Jornalismo, Ética e Liberdade" e "A Ética Jornalística e o Interesse Público", têm como foco a discussão das questões éticas relativas à cobertura e o envolvimento dos veículos de imprensa em episódios específicos da história brasileira. Entre estes, destacam-se a onda de privatizações do governo $\mathrm{FHC}$ e a entrevista do cantor Cazuza à revista Veja. Ao longo de sua trajetória como professor do curso de Jornalismo na UFSC, ministrou, entre outras disciplinas, a de "Legislação e Ética do Jornalismo", trazendo aos alunos os debates levantados em sua produção acadêmica.

Para abordarmos as questões que Karam discute sobre estes temas aplicados ao jornalismo, é necessário trazer as definições que ele utiliza de ética, moral e deontologia:

Em sua origem, ética e moral tinham significado quase idêntico, o de caráter, costume, maneira de ser, sendo que o primeiro termo é derivado do grego ethos, enquanto o segundo é originário do latim moralis. Deontologia, derivado do grego deontos, significa o que deve ser, isto é, a cristalização provisória do mundo moral, validado pela reflexão ética, em normas sociais concretas, em princípios formais e, em alguns casos, em normas jurídicas. A normatização deontológica de regras e condutas morais reflete, portanto, a sistematização social daquilo que existe na esfera moral e é objeto da reflexão ética.

Trazendo ao âmbito jornalístico, Karam afirma que ao falar de ética no jornalismo, estamos lidando com "algo que parte de valores constituídos humanamente para chegar a atos praticados humanamente" (KARAM, 2004, p. 123).

Já a deontologia é interpelada pela ética, operando no "terreno do exercício profissional com base nos valores que fundamentam as regras e as formulações" (KARAM, 2004, p. 125). A presença e a importância do jornalismo perante a sociedade trouxe a necessidade da preocupação com a questão ética, já que cada vez mais existe uma complexidade social, que cresce junto com a mediação que os meios exercem sobre a realidade. Assim, em função de o jornalismo mostrar o mundo em sua diversidade de fatos e versões, coloca-se uma necessidade de fazer uma distinção entre os fatos de relevância pública e a responsabilidade com a publicação dos mesmos, com a garantia ao direito à informação em mente. 
Neste sentido, a construção de uma ética humanista e universal - que não dilua o indivíduo, mas que o mantenha como ponte com o outro - é fundamental para tentar resolver o impasse entre o direito social à informação, a mediação profissional do jornalista e a realidade em reconstrução cotidiana pelos veículos de comunicação, por meio da informação imediata apropriada em conjunto por aqueles que a produzem (KARAM, 1997, p. 21)

O jornalismo, devido ao seu papel mediador na sociedade, precisa de uma reflexão sobre o processo de produção e veiculação diária da informação e das consequências que dele resultam. A partir de nossa leitura da obra de Karam, também é necessário refletir sobre a importância de informar esses fatos abrangentes e complexos para que as pessoas tanto tomem conhecimento quanto se manifestem com relação a eles e sobretudo compreendam e utilizem as informações para se movimentarem na realidade cotidiana. É importante considerar as diferenças pessoais de cada um, trazendo atos, opiniões próprias e a necessidade de se balancear tudo isso na produção diária. Por isso, Karam defende a indispensabilidade da criação de uma teoria que aborde a ética jornalística, o que traremos adiante.

Quanto aos códigos de ética do jornalismo, Karam entende que os profissionais devem levar em consideração os textos contidos em suas páginas, procurando o fim de crimes e afirmando seu desejo por uma sociedade onde os problemas não existam (KARAM, 2009, p. 43). Argumenta que os códigos de ética ao redor do mundo, assim como os tratados e declarações internacionais - ou pelo menos parte deles -, possuem valores profissionais ditos universais, como a isenção, a busca pela verdade, a defesa do bem social, entre outros. Mas com relação à criação do conteúdo desses códigos, fica uma questão importante: a necessidade de uma vinculação dos princípios ao concreto e ao cotidiano, para evitar que os códigos caiam na subjetividade, correndo riscos de serem distorcidos por diferentes pessoas com vistas a uso em favor próprio. Também podendo criar problemas na concepção dos valores éticos em países que não possuem uma liberdade de imprensa ou tradições próximas as dos países ocidentais, cujos valores são usados como base no desenvolvimento dos códigos e tratados internacionais.

Assim como a ética, a questão moral no jornalismo tem se tornado cada vez mais importante nos tempos atuais de crise de credibilidade da mídia jornalística, provocada, entre outras causas, pelas movimentações nas redes sociais e a agudização do fenômeno das fake news. E a moral não está presente somente no exercício da profissão jornalística. Apresenta-se também nas matérias produzidas pelos profissionais, Revista Pauta Geral-Estudos em Jornalismo, Ponta Grossa v.5, n.2, p. 147-163, Jul/Dez 2018. 
aparecendo em praticamente todos os cadernos e editorias, de cidade à internacional, de política à cultura. Assim, o jornalismo acaba vendo-se obrigado a lidar com ambas as questões, além da dificuldade de interpretar os fatos em um espaço de tempo cada vez mais curto, o que tem levado a problemas de apuração e checagem.

O jornalismo é, e vem sendo cada vez mais, alvo constante de diversas críticas, inclusive partindo de jornalistas, relativas a questões éticas e morais. Karam sai em defesa da profissão, destacando sua importância para a humanidade:

O jornalismo não é só moralmente defensável. Ele é moralmente imprescindível. Ou seja, em sua potencialidade, o jornalismo é a forma pela qual as pessoas vão se apropriando cotidianamente de seu movimento no interior da humanidade e, desta, em sua autoprodução diária. E extraem daí sensibilidade, movimento, opinião, intervenção diante dos enormes e complexos conflitos irresolvidos pelo gênero humano (KARAM, 1997, p. 39)

\section{Teoria do jornalismo e da ética jornalística}

A formulação de uma teoria específica do campo jornalístico, que ajudasse na sua consolidação no meio acadêmico, é sempre defendida por Francisco Karam em toda sua obra. Entre as razões dadas para essa postura teórica e profissional, está a "busca da defesa e da consolidação de determinados valores", o que pode ser atingido por meio da "ampliação e de manutenção de campos específicos de estudos, de pesquisas e de processos de formação profissional" (KARAM, 2004, p. 125).

Sobre a importância do fortalecimento do campo jornalístico com a formulação de uma teoria própria, o professor e pesquisador ainda argumenta:

Só mesmo a práxis jornalística, inserida no contexto geral dos desdobramentos sociais da humanidade, pode fazer com que o jornalismo tenha algum engrandecimento e tenha alguma potencialidade revolucionária diante do "andar natural e espontâneo" do mundo. A teorização sobre a atividade é fundamental. Os desdobramentos éticos e morais disso também. Da mesma forma, a ação política cotidiana do profissional (KARAM, 1997, p. 47)

A formulação de uma teoria específica do jornalismo também seria útil para poder pensar o fazer jornalístico e suas implicações na sociedade. Com essa teoria e o consequente fortalecimento do campo como da própria profissão, o jornalismo poderia mostrar-se efetivamente como necessário para a humanidade, o que se torna ainda mais importante na contemporaneidade. 


\begin{abstract}
O papel da teoria, nesse aspecto, é pensar a prática e suas implicações imediatas para poder, pela crítica, repensá-las em novas bases. As consequências sociais da atividade jornalísticas são grandes e evidentes. Pensar a prática é uma forma de contribuir para que ela, pela intervenção da crítica teórica, adquira novos procedimentos, conforme alguns, melhore outros. A pretensão da teoria é precisamente esta, evitar que o futuro seja um conformado refém do presente e mostrar que qualquer atividade e qualquer reflexão sobre a prática estão juntas num mesmo processo e em seu desdobramento no tempo (KARAM, 2004, p. 17)
\end{abstract}

A interdisciplinaridade também é aspecto indispensável a ser pensado na construção da teoria do jornalismo. Atualmente, a interdisciplinaridade se faz bastante presente não somente na formação, mas também como exigência que se evidencia na atuação do profissional no cotidiano do fazer jornalístico. Na Universidade, o ensino de jornalismo conta também com disciplinas de áreas como filosofia, política e tecnologias, enquanto na profissão, o jornalista pode se deparar com os mais diversos tipos de conhecimento. Assim, a existência de um campo epistemológico e ontológico próprio auxiliaria o jornalismo no seu relacionamento com a totalidade.

Para Karam, os estudos de ética também são essenciais na formulação de uma teoria do jornalismo. Entende ser necessária igualmente a construção de um espaço para a teoria ética para o jornalismo, com a função de "responder a questões complexas e irresolvidas sobre a atividade" (KARAM, 1997, p. 44).

Com essa perspectiva, os debates envolvendo a ética no jornalismo conseguiriam ir além de algumas concepções que já viraram lugares-comuns. Todos com uma tendência a diminuir a importância do estudo da ética na formação do profissional, como "ou se é ético ou não se é", "ética não se aprende", "jornalista nasce feito", entre outros (KARAM, 2004, p. 119).

Karam (1997, p. 28) ainda defende que uma teoria do jornalismo e da ética jornalística podem representar uma evolução do campo, trazendo um novo futuro:

A constituição de um campo ético no jornalismo deve reconhecê-lo como uma atividade imprescindível contemporaneamente para o conhecimento global e imediato da realidade, em sua aparência de relatos de fatos e nas concepções que embalam as versões. Também a constituição de uma teoria do jornalismo, que o reflita e o projete à frente - não como refém da prática, mas como insubmissão diante dela -, levando em conta as amplas possiblidades de esclarecimento do mundo e da resolução de problemas reconhecidos como tal, contribuindo para a formação de 
sujeitos "políticos, teóricos, éticos e morais", é um passo indispensável para um futuro que não seja apenas arremedo do presente.

\section{O jornalismo do século XXI}

A revolução tecnológica e as suas implicações para o jornalismo e a ética foram reflexões sempre presentes na obra de Francisco Karam, aparecendo com mais incidência nos últimos 10 anos, momento em que as mudanças estruturais provocadas pelas mais recentes novas tecnologias das comunicações, como a internet, intensificaram-se e modificaram profundamente o relacionamento da sociedade com a informação e o profissional do jornalismo.

O conjunto de informações produzido hoje é maior do que há 10 anos, bem maior do que há 30 anos, infinitamente maior do que há 200 anos. A circulação das informações permitida de forma imediata pelos suportes tecnológicos cada vez mais sofisticados, além de ter volume maior, dá-se de forma mais intensa e rápida (KARAM, 2005, p. 77)

Uma preocupação levantada por Karam na atual configuração da Sociedade da Informação, por ele conceituada de Sociedade da Informação e do Conhecimento, é a necessidade de defesa e reafirmação da profissão e dos valores inerentes ao jornalismo. Com a nova conformação comunicacional, onde o receptor deixa de ser apenas um receptor e passa a ter os meios de produzir e disseminar informações com a velocidade e o alcance da transmissão de conteúdo possibilitados sobretudo pelas redes sociais, tornam-se imperativos a manutenção e o fortalecimento de valores como a credibilidade e o interesse público, reforçando a necessidade do jornalismo e do jornalista na atualidade.

O sentido público do jornalismo na Sociedade da Informação é uma das dúvidas levantadas por Karam em sua obra. Estaria esse sentido, com sua base nos valores, em crise ou seria um momento de reafirmação do sentido público através de características próprias do jornalismo presente nos novos produtos, atores e outros fatores propiciados pela revolução tecnológica? (KARAM, 2009, p. 18) Independente da resposta, Karam reafirma a necessidade do campo manter e reforçar seus valores. Segundo ele, o jornalismo:

(...) não pode abrir mão dos princípios ético-deontológicos que o alicerçaram como um interrogador público contemporâneo que se impõe um mandato sem fim a favor da representação controversa do espaço público normativo, seja macro, médio ou micro. Por isso, os valores 
clássicos do jornalismo significam defender a própria atividade como específica e incontornável; que o jornalismo é mais do que aventura ou acaso; é a razão de ser da controvérsia pela qual se valora e decide sobre o mundo imediato da forma mais lúcida possível; e que está na base da vitalidade democrática. (KARAM, 2009, p. 26)

$\mathrm{Na}$ Sociedade da Informação e Conhecimento, mesmo com todas as transformações enfrentadas pelo jornalismo, os critérios e os valores devem continuar sendo os mesmos. Para Karam (2009, p. 50), estes valores passam a ter uma importância ainda maior, com a emergência da informação segmentada. Esses critérios e valores devem se estender a todo trabalho jornalístico, devido à enorme quantidade de fatos, versões e áreas de conhecimento. Assim, o jornalismo pode passar a "ser portador de uma credibilidade que o qualifique para a representação social" (KARAM, 2010, p. 283)

De acordo com Karam, um dos principais problemas que o jornalismo enfrenta atualmente tem origem na questão dos conglomerados midiáticos e as megafusões empresariais. Os veículos de mídia passaram a ser apenas um ramo dos negócios empreendidos por seus donos, o que levanta sérios problemas éticos como conflitos de interesse. Essa espécie de dicotomia deriva do fato de que tratam o jornalismo apenas como negócio enquanto seus códigos de ética reafirmam o que são chamados de "princípios e valores inalienáveis, como verossimilhança, interesse público, isenção, pluralidade, respeito à privacidade, independência, credibilidade, exatidão" (KARAM, 2010, p. 282).

\section{O ensino de jornalismo}

Ao longo de sua trajetória no campo acadêmico, Karam também refletiu sobre o ensino de Jornalismo em suas produções, debatendo questões que vão desde as disciplinas e temas necessários à formação de um profissional até o embate teoria versus prática. Reflexões que até hoje permanecem atuais e pertinentes para aspectos como o trabalho de conclusão de curso dos estudantes.

O professor e pesquisador concorda e defende a visão de que a formação profissional para o exercício do Jornalismo requer tanto qualificação técnica quanto teórica, de maneira equilibrada, conforme comenta em um de seus artigos (KARAM, 2012, p. 108): 
Uma formação com tal perspectiva que vincule as reflexões na área ao seu resultado concreto, por meio de um produto, e da consequente e qualificada forma de obter um emprego, implica reconhecer que deve equilibrar os aspectos teóricos, epistemológicos e fenomenológicos do jornalismo com a produção diversificada e plural em distintos suportes tecnológicos. (KARAM, 2012, p. 108)

Assim, as grades curriculares dos cursos de Jornalismo devem contar com disciplinas de ordem reflexiva e também práticas laboratoriais, que possibilitem aos futuros jornalistas exercitar tanto as capacidades de pensamento, crítica e questionamento como as de execução. Ou seja, que permitam a aplicação no conhecimento teórico na prática e, vice-versa, a reflexão sobre a prática no ensino teórico. E para Karam, podem ser ensinadas após as primeiras ou até mesmo simultaneamente, tudo isso utilizando referências jornalísticas que sejam históricas ou que tenham relação com a importância social do campo. Com relação ao ensino de ética, Karam defende uma abordagem mais ampla, que inclua "história, valores e ethos profissional" (2004, p. 120) e os estudos aplicados à profissão. Mais: para ele, este ensino deve lidar com a ética e a deontologia em conjunto, em um processo constante.

Especificamente sobre os trabalhos de conclusão de curso, em artigo de 2004, discutiu a questão da resistência de algumas universidades e faculdades em permitir que os alunos desenvolvam Grandes Reportagens ou Projetos Experimentais ao invés de apenas monografias. Nesse artigo, Karam defende a liberdade dos alunos em produzir o trabalho com o qual se sintam mais confortáveis, e ressalta a interdisciplinaridade do campo jornalístico. Assim, destaca que os cursos que permitem tais produtos como trabalho final auxiliam não só o campo do conhecimento, mas também a liberdade de pensamento, a qualificação da profissão, além do retorno social, algo de suma importância, principalmente nas universidades públicas (KARAM, 2004, p. 10). Ainda sobre a questão, ele comenta:

Se o jornalismo, como acredito, é uma forma de conhecimento sobre o cotidiano, em escala massiva, planetária, imediata, em períodos curtos, possibilitando aos outros o acesso ao entorno social, por meio de fatos e de relatos sobre eles, que incluem fontes, dados, interpretações e conhecimentos produzidos por infinitas áreas, da Sociologia à Biotecnologia, a exclusão da possibilidade de concluir o curso com uma Grande Reportagem atesta a desconfiança com a própria área do saber. E reduz a própria importância da profissão, quase negando o produto profissional, atribuindo a ele algo menos qualificado ou "menor" (KARAM, 2004, p. 4) 
Ao produzirem Grandes Reportagens ou Projetos Experimentais nos trabalhos de conclusão de curso, conforme ele, os estudantes conseguem "um espaço privilegiado para o exercício e consolidação" das teorias e debates ensinados em aula sobre ética, deontologia e responsabilidade social e moral, fugindo assim de uma versão tecnicista desse tipo de produto. (KARAM, 2004, p. 11)

\section{Considerações}

Nesta época contemporânea a área da comunicação e sobretudo o jornalismo adquirem cada vez mais centralidade como construtores da realidade social. Com o advento e agora o crescente aumento do acesso à internet, a expansão da importância das redes sociais no dia a dia da população e a quebra dos padrões de produção e circulação de conteúdo entre emissor e receptor, a agudização do fenômeno fake news e a sua inegável crise como modelo de negócios, entre outros impactos dos tempos atuais, o jornalismo vem atravessando um período de transformações de novo determinantes e que exigem que demonstre e consolide sua necessidade e sua importância para a humanidade.

Nos últimos anos, entretanto, justamente por conta deste contexto, entre outras ameaças que chegam até a decretar que se trata do fim do jornalismo, este tem enfrentado crises, sendo uma das mais intensas a de credibilidade. Por exemplo, tornouse comum e cotidiano ver, em posts no Facebook ou no Twitter dos veículos de comunicação ao redor do mundo, comentários que criticam a imprensa, acusando-a principalmente de tendenciosa e de prática de fake news. O fenômeno das fake news se agravou com a campanha de Donald Trump à presidência dos Estados Unidos, permeada por denúncias de informações falsas e manipuladas.

No Brasil, o mais recente exemplo da crise de credibilidade que a imprensa atravessa está na pesquisa DataFolha divulgada dia 10 de junho de 2018. Pela pesquisa, a imprensa amarga desconfiança de $37 \%$ do povo brasileiro e pouca confiança de parte de $45 \%$. Apenas $16 \%$ dos brasileiros responderam que confiam totalmente na mídia jornalística do país. Uma crise de credibilidade que também abala, e com muito mais força, outras instituições basilares do país. A título apenas de conhecimento, é nesta mesma pesquisa que Michel Temer tem seu governo avaliado como ruim ou péssimo por $82 \%$ dos brasileiros, tornando-se o presidente mais impopular da história do país. 
Por isso, os debates em torno do campo jornalístico e da ética são ainda mais importantes para que os profissionais saibam lidar com essa pressão que é muito maior hoje. Essas situações são bem exemplificadas nos casos que Francisco Karam discorre sobre, principalmente em seus dois livros.

Ao ir das técnicas que posteriormente ajudaram a fundar o jornalismo até as questões essenciais da produção e do campo jornalístico, Karam desenvolveu uma obra importante para as discussões sobre não só a atuação profissional, mas também a afirmação do jornalismo como um campo do conhecimento, defendendo a criação de uma teoria própria do jornalismo. Karam defende, e o autor concorda, que seria um passo importante para a consolidação da área. E nos últimos anos, isso tem se mostrado ainda mais importante, com os debates acerca da obrigatoriedade do diploma.

Durante sua trajetória acadêmica, Karam trouxe debates importantes que se concretizariam anos depois. Por isso, sua obra se tornou referência nas análises sobre a ética jornalística. Somado à sua experiência profissional, no mercado, sua defesa do ensino de jornalismo e da ética é bastante relevante, principalmente por sair em defesa dos projetos experimentais como uma possibilidade de trabalho de conclusão de curso, algo que ainda é abominado em algumas universidades pelo país e pelas listas de tópicos essenciais para a criação de disciplinas sobre ética e deontologia no jornalismo, mostrando assim a importância dessas cadeiras para a formação de novos profissionais.

\section{REFERÊNCIAS BIBLIOGRÁFICAS}

BOGHOSSIAN, Bruno. Reprovação aumenta e torna Temer o presidente mais impopular da história. Folha de S. Paulo, 10 jun. 2018. Disponível em: https://www1.folha.uol.com.br/poder/2018/06/reprovacao-aumenta-e-torna-temer-opresidente-mais-impopular-da-historia.shtml. Acesso em: 11 jun. 2018

KARAM, Francisco José Castilhos. Jornalismo, Ética e Liberdade. São Paulo: Summus, 1997

KARAM, Francisco José Castilhos. A Ética Jornalística e o Interesse Público. São Paulo: Summus, 2004.

KARAM, Francisco José Castilhos. Ética, deontologia, formação e profissão: observações sobre o Jornalismo. Estudos em Jornalismo e Mídia, Florianópolis, v. 1, n. 1, p. 118-130, jan-jun., 2004 
KARAM, Francisco José Castilhos. Conhecimento e Formação Graduada em Jornalismo no Brasil. Revista PJ:Br, São Paulo, v. 4, p. 4, 2004. Disponível em: http://www2.eca.usp.br/pjbr/arquivos/artigos4_h.htm. Acesso em: 30 dez. 2017

KARAM, Francisco José Castilhos. O Presente possível do Jornalismo. Estudos em Jornalismo e Mídia, Florianópolis, v. 2, n. 2, p. 75-81, jul-dez., 2005

KARAM, Francisco José Castilhos. 20 anos de O Segredo da Pirâmide. Estudos em Jornalismo e Mídia, Florianópolis, v. 4, n. 1, p. 167-176, jan-jun., 2007

KARAM, Francisco José Castilhos. Jornalismo e ética no século XXI. Anuário Unesco I Metodista de Comunicação Regional, São Bernardo do Campo, v. 13, n. 13, p. 15-27, jan-dez., 2009. Disponível em: https://www.metodista.br/revistas/revistasims/index.php/AUM/article/view/2185. Acesso em: 10 jan. 2018

KARAM, Francisco José Castilhos. The paradigma of Antigone and Gacel Sayah: Na approach to historical and contemporary Ethical / moral dilemmas of Journalism. Brazilian Journalism Research, Brasília, v. 5, n. 2, p. 37-52, dez, 2009. Disponível em: https://bjr.sbpjor.org.br/bjr/article/view/210. Acesso em: 09 jan. 2018

KARAM, Francisco José Castilhos. Retórica, Grécia e Roma Antigas: vestígios da futura linguagem jornalística. ALCEU, Rio de Janeiro, v. 10, n. 19, p. 109-117, jul-dez., 2009. Disponível em: http://revistaalceu.com.puc-rio.br/media/Alceu19_Karam.pdf. Acesso em: 07 jan. 2018

KARAM, Francisco José Castilhos. Alguns apontamentos e um futuro aberto: sociedade da informação e do conhecimento, convergência tecnológica, diversidade midiática e ciberjornalismo. Revista FAMECOS, Porto Alegre, v. 17, n. 3, p. 278-285, set-dez, 2010. Disponível em: http://revistaseletronicas.pucrs.br/ojs/index.php/revistafamecos/article/view/8195. Acesso em: 06 jan. 2018

KARAM, Francisco José Castilhos. Jornalismo, controvérsia e convencimento: a palavra e a formação. Verso e Reverso, São Leopoldo, v. 26, n. 62, p. 103-108, mai-ago, 2012. Disponível

em: http://revistas.unisinos.br/index.php/versoereverso/article/view/ver.2012.26.62.05. Acesso em: 06 jan. 2018

KARAM, Francisco José Castilhos; HAUSER, Vanessa. Retórica e Dialética: o tributo do jornalismo aos greco-romanos. Estudos em Comunicação, Covilhã, n. 10, p. 273-291, dez, 2011. Disponível em: http://www.ec.ubi.pt/ec/10/pdf/EC10-2011Dez-15.pdf. Acesso em: 08 jan. 2018

Recebido em: $11 / 06 / 2018$

Publicado em: 21/12/2018 